\title{
Threats and opportunities for post-closure development in dolomitic gold-mining areas of the West Rand and Far West Rand (South Africa) - a hydraulic view Part 2: Opportunities
}

\author{
Frank Winde* and EJ (Leslie) Stoch \\ North West University, Potchefstroom Campus, Private Bag X6001, Potchefstroom 2520, South Africa
}

\begin{abstract}
Largely dependent on gold mines for their economic survival, many mining towns in the Far West Rand fear the effects of the inevitable impact of mine closure, not only on the economy but also on social stability. Large-scale environmental degradation in the form of sinkholes and widespread radioactive pollution exacerbate such fears. Based on an analysis of mining impacts and potential threats for post-mining developments provided in Part I, this $2^{\text {nd }}$ paper in a 3-part series aims to stimulate thought, through the discussion of potential opportunities centred on the rich water resources of the area. This is in full recognition of a subsequent need to assess the economic and technical feasibility of identified opportunities in more detail. Many opportunities are based on the concept that perceived mining liabilities may have the potential to be turned into assets. Examples include the restoration of dewatered karst aquifers and their use for storing large volumes of water, protected from evaporation losses, combined with artificial groundwater recharge and harvesting as well as underground generation of hydropower. This could well be complemented by other water-based developments such as aquaculture, agriculture and different forms of tourism relating to water, karst and mining. Possibilities for using waste land such as sinkhole areas and slimes dams include the establishment of a large game reserve on donated land as well as using tailings for biofuel production and generating solar- and wind-based electricity. Lastly, the re-establishment of a uranium-related industry is explored; this could capitalise on existing infrastructure and former expertise and benefit from the envisaged development of uranium as a strategic resource in SA. In view of the current media attention given to negative environmental and health effects, it is, however, questionable whether such development would be acceptable to local residents.
\end{abstract}

Keywords: post-mining development, karst, groundwater storage and harvesting, subterranean hydro-energy generation, tourism, wasteland transformation, uranium industry, research opportunities

\section{Introduction}

Based on the analysis of century-old mining impacts relating to deep-level gold mining, and their potential to threaten sustainable post-mining developments (Winde and Stoch. 2010a), this paper aims mainly to stimulate ideas and concepts on how to meet the challenges associated with mine closure. Owing to the nature of such an approach it must be stressed that all concepts presented will need further investigation to establish technical and, more importantly, economic feasibility.

\section{Post-mining development opportunities}

\section{Research opportunities}

In view of the serious repercussions that uncontrolled rewatering may have on the environment, it is imperative to prevent worst-case scenarios by proactively addressing the issue in cooperation with the gold mines, while they are still operational. In order to achieve this, sufficient data and scientific understanding must be obtained, as well as retained, which includes making use of access to underground facilities

\footnotetext{
* To whom all correspondence should be addressed.

용 +2718 299 1582; fax: +27182991582 ; e-mail: frank.winde@nwu.ac.za

Received 5 August 2009; accepted in revised form 9 December 2009.
}

for as long as this is still possible. The process of obtaining sufficient knowledge on re-watering consequences simultaneously provides a unique opportunity to study karst hydrology, including analysing dynamics and consequences of dewatering, as one of the world's largest karst field experiments, unprecedented in depth, magnitude and scale. In view of the fact that karst systems, worldwide, rank amongst the most important groundwater resources, many of which face increased threats of pollution, the current gaps in knowledge on karst hydrology, in general, and intra-karst contaminant transport, in particular, present a unique opportunity to place the Far West Rand (FWR) on the scientific world map. This is even more so in view of the unrivalled mass and density of available historical data generated over the past 60 or so years of active dewatering, ranging from water quality records, flow gauging, pumping volumes and borehole observations to hundreds of kilometres of documented drilling cores, long time-series of monthly surface level monitoring records, karst tracer experiments and large-scale gravimetric surveys, to name but a few. In fact, the extent, density and quality of such data could only have been afforded by the contribution, at the time, of the world's richest gold mines. Efforts are currently underway at the Water Research Group of the NWU (Potchefstroom Campus) to tap into this wealth of data by retrieving, collating and archiving available data and information using Geographical Information Systems (GIS), electronic databases as well as a hard copy library currently containing some 4000 entries. 
With widespread uranium pollution present in the Wonderfonteinspruit (WFS) catchment, the area also provides unique research opportunities for tracing the fate of uranium as a non-ubiquitous, radioactive heavy metal emitted, almost exclusively, from mining sources for more than a century, and which subsequently migrated through all spheres of the environment (for a small selection out of the numerous sources on this topic see IWQS, 1999; Wade et al., 2002; Coetzee et al., 2002; 2006; Winde, 2006a; b; c; Barthel, 2007; Winde, 2009). Apart from understanding pathways and transport mechanisms in water, sediment and soil, planned research aims to include bioaccumulation, mobility along the food chain and epidemiological studies. Historical examples illustrate that the investigation of exceptional pollution levels in mining areas of the Witwatersrand Basin in the late 1960s pioneered a research discipline which was later extended to the developed world (e.g. Wittmann and Förstner, 1977).

\section{Karst-related opportunities}

Owing to the presence of chert-rich formations in the up to $1600 \mathrm{~m}$-thick dolomites in the WFS, deep chemical weathering could take place which resulted in the development of exceptionally extensive karst features in the 2.6 billion-year-old rock. Examples include:

- The 6 longest caves surveyed in Southern Africa, which are located in these dolomites, some exceeding $14 \mathrm{~km}$ in total passage length and reaching up to $180 \mathrm{~m}$ below the surface, and surpassing well-known tourist attractions such as the Cango Caves in Oudtshoorn, South Africa, by far

- The 3 strongest karst springs in the southern hemisphere were located here, the Gerhard Minnebron Eye (long-term average flow: $\sim 60 \mathrm{M} \ell / \mathrm{d}$ (still flowing)), Oberholzer Eye ('Eye of the Wonderfontein' discharging $55 \mathrm{Ml} / \mathrm{d}$ before drying up in 1959) and Bank Eye ( $\sim 50 \mathrm{M} / \mathrm{d}$, dried up in 1959) (Swart et al., 2003a)

- One of the largest paleo-sinkholes/dolines in South Africa is found near Doornfontein Gold Mine (GM)

- Some of the largest groundwater resources in Southern Africa are located here, with the 3 dewatered compartments totalling a storage volume of $3500 \times 10^{6} \mathrm{~m}^{3}$ (Swart et al., $2003 \mathrm{a}$; b) exceeding the Vaal Dam volume at full capacity $\left(2536 \times 10^{6} \mathrm{~m}^{3}\right)$

It is suggested that post-mining development efforts explore opportunities to capitalise on the existence of these exceptional karst features, based on an improved understanding of karst processes as outlined before. Possible areas of such utilisation may range from groundwater storage and harvesting, to underground power generation and irrigation, to unlocking the potential for tourism and research, to name but a few. Some of these aspects are outlined below.

\section{Active groundwater recharge and harvesting}

In contrast to most other countries, water supply systems in South Africa currently rely mostly on surface water instead of groundwater, with large volumes of water stored in shallow dams. Owing to semi-arid conditions where evaporation from open water surfaces exceeds gains from rainfall by up to a factor of 3, a large proportion of the stored water is lost to the atmosphere (at the Vaal Dam, for example, evaporation losses equal approximately a third of the total inflow, calculated from data presented by DWAF (2008)). Since the combined effective storage volume of the dolomitic compartments in the FWR area exceeds the storage capacity of the Vaal Dam by far, research should be initiated to explore the possibility of karst aquifers being used as actively-managed water reservoirs to store water largely protected from evaporation. While there have indeed been efforts by DWAF (now the Department of Water Affairs (DWA) and the Department of Environmental Affairs (DEA)) to explore the potential of the FWR dolomites as an emergency water supply source for nearby Gauteng (Enslin and Kriel, 1971; Vegter, 1983; Connelly and Rosewarne, 1984; DWAF, 2005), up to the present, to the knowledge of the authors, no concrete development strategy has emerged. The evaporationprotected storage of water could be accompanied by active reservoir management including artificial groundwater recharge aimed at storing surplus (runoff) water underground during wet periods, possibly even using suitable sinkholes as recharge conduits.

In the Klerksdorp goldfield, where large-scale dewatering and mine closure also threatened remaining operations, DWAF in 2006, for the $1^{\text {st }}$ time ever, approved the joint establishment of water utilities by 4 different mines, aimed at recovering pumping costs through commercialising the pumped groundwater. Based on these experiences, it should be explored to what extent the use of such a model could provide sustainable income for post-mining communities. In the case of the FWR, existing water purification plants of gold mines could complement the conversion of pumping shafts into water utilities owned and run by the municipality. The possibility, in principle, of sustainably using dolomitic groundwater for commercial water supply systems is successfully demonstrated by the Rand Water Pumping Station at Zuurbekom, which has used the good quality groundwater from the Zuurbekom Compartment for over 100 years to supplement its water supply to Gauteng households (Rand Water, 1904 et seq.). The possibility of using an 'industrial' circuit of non-potable water for mining purposes has also been suggested. With water increasingly becoming a limiting factor for any type of economic activity in semi-arid parts of South Africa, such water-centred development may well yield economic spin-offs by further attracting water-dependent industries.

\section{Subterranean hydropower generation}

The basic principle of underground hydropower generation is based on utilising elevation differences between adjacent compartments and associated karst cavities in much the same way that the ESKOM pumping scheme at the Sterkfontein Dam in the Drakensberg works, i.e., driving turbines which generate electricity in peak demand times (daytime) and pumping the water back to the upper reservoir at cheaper night-time tariffs. A similar system is currently installed in karst areas of Indonesia, where underground flow drives irrigation pumps bringing the water back to the surface at minimal pumping costs (Zuber-Knost, 2003). With deep shafts and large voids created by mining, this technology may be able to utilise not only karst voids and natural gradients but also some of the underground infrastructure such as shafts, haulages and existing mine-water reservoirs. The Kloof Mine is reportedly already using hydropower in its underground operations and may consider a larger scale expansion (Jacobs, 2008).

Depending on the possible implementation of active groundwater recharge and harvesting schemes mentioned 
above, post-flooding water levels in the dolomitic compartments could be kept at such elevations that near-surface karst cavities at different levels could be connected through existing shafts or other conduits and utilised for underground hydropower generation even after re-watering. Apart from being 'climate-neutral', underground hydro-power generation right in the economic heartland of South Africa, where the energy is needed, would also reduce transmission losses, which, in centralised networks such as the one currently maintained by ESKOM, can be significant. It must be stressed, however, that this can only be implemented once the impacts of deep-level gold mining on the litho- and hydrosphere are sufficiently understood and subsequently addressed. This includes water quality threats, such as long-term pollution through acid mine drainage from sources on the surface and underground and through tailings deposited directly in the aquifer, as well as water flow aspects, such as the hydraulic consequences of the penetration of dykes that formerly hydraulically separated adjacent dolomitic compartments, the consequences of diverting the stream flow of the WFS out of its natural bed into a pipeline (e.g. drying up of the associated wetland, loss of natural groundwater recharge, etc.), the effects of sinkholes on the runoff-recharge relationship in affected areas, the effects of rising groundwater levels on ground stability, the lack of dilution for insufficiently-purified sewage effluents during the decades of re-watering when no water is pumped, and many other aspects. Dedicated research projects need to be initiated well in advance of any mine closure to ensure that needed data, expertise and financial support are used while they are still accessible and available. Such projects will need to be based on a close collaboration between scientists, mining experts, governmental departments and affected municipalities.

\section{Hydrothermal energy generation}

With the final depth of many mines in the FWR predicted to be in the region of $4000 \mathrm{~m}$ below the surface, a significant increase in rock-face temperatures in the deep part of the mine voids can be expected, following the geothermal gradient. It should be explored to what extent this geothermal energy can be used to provide a decentralised source for heating nearby homes and possibly also hydroponic facilities (greenhouses producing high-value horticultural products), utilising heatexchange technologies which have greatly improved in recent times. A current research project in Germany found that $3 \mathrm{M} \ell / \mathrm{d}$ of decanting mine-water from a void only $1000 \mathrm{~m}$-deep already displays a temperature of $40^{\circ} \mathrm{C}$ - enough to heat some 200 family homes (Giegerich, 2008). In view of potentially higher water temperatures (rock-face temperatures at $4 \mathrm{~km}$ depth are around $60^{\circ} \mathrm{C}$ ) and much higher decant volumes ( $>150 \mathrm{M} \ell / \mathrm{d}$ ), over 10000 homes (a $1^{\text {st }}$ order estimate) could possibly be heated in the study area.

\section{'Aqua production' and application of 'virtual water' concept}

Complementing activities associated with the development of a water-hub in the FWR could include the establishment of large-scale aquaculture projects providing a local source of fish-based protein with accompanying employment opportunities. Depending on demand, the introduction of upmarket products such as freshwater shellfish, eel and others as export commodities could be considered. Feasibility studies need to address to what extent existing dams could be used as fishponds, and how potentially adverse impacts on water quality in underground reservoirs (e.g. eutrophication) are to be avoided.

Owing to the diversion of streamflow and artificial concentration of discharge at the lower part of the WFS, a number of new large reed-beds developed, while existing wetlands grew significantly. Examples from KwaZulu-Natal and the Western Cape illustrate how these fast-growing plants could be harvested and used for producing a range of products, including bags, mats, furniture, roof covers, etc., instead of perceiving the reeds as weeds that choke rivers and streams and thus need to be eradicated and burnt, as is currently practised in much of the study area.

In view of the general scarcity of water in semi-arid South Africa, and the possibility of further shortages in the future as a result of climate change, it needs to be stressed that water should increasingly be used cost-efficiently, based on the concept of 'virtual water'. For example, instead of, as currently practised in the area, using large volumes of water for irrigation of low-revenue generating crops such as maize, which elsewhere grows without additional watering, ways should be explored to generate higher revenues with less water (e.g. producing high-value horticultural products). This could increase the monetary water-use efficiency while achieving water sustainability. The surplus of generated revenue could then be used to import water-intensive crops from countries or areas where they can be produced more cost-effectively and using less water. Current examples of such attempts are 2 hydroponic projects initiated and sponsored by Gold Fields Limited (GFL), which are aimed at promoting post-mining sustainable development in the area by producing roses for the European market and vegetables for local consumers, respectively.

\section{Tourism opportunities}

With claims that tourism in South Africa had already overtaken the mining sector in revenue generation a couple of years ago, the tourism sector may well complement the post-mining economy in the study area. Situated between 2 sites of global significance, i.e., the UNESCO World Heritage Site of the Cradle of Humankind at the Sterkfontein Caves in the north and the world's largest and oldest meteorite impact structure at the Vredefort Dome in the south, the WFS catchment is strategically well-positioned to tap into existing tourism markets. Both sites are directly and indirectly related to unique features in the FWR, i.e., exceptional karst features (the same type of dolomite that allowed the caves at Sterkfontein to form and to trap early hominids) and gold mining, which would have been impossible without the impact of the meteorite at the Vredefort Dome forcing parts of the auriferous reefs to surface. In the following section some examples for developing the tourism potential of both themes, i.e., karst and mining, are outlined.

\section{Karst-related tourism}

With the UNESCO World Heritage Site at Sterkfontein and the adjacent Maropeng Museum both dedicating sections to karst, water and cave development and their role for early hominids, these sites could be organically linked to the study area where the largest caves in Southern Africa are found. Some of the caves could, for example, be opened for guided tours, not only 
for exploring the scenic value but also for anthropological and ecological aspects, including the established shelter functions that caves served for early tribes in the area (e.g. Kleinfontein Cave), the occurrence of endemic fauna such as the white rat (found at Abe Bailey Nature Reserve), as well as cave dwellers such as bats and certain aquatic organisms. Special habitats associated with the large paleo-sinkhole at Doornfontein, where a breeding pair of a rare eagle species can currently be found, may also fall into this category.

It should further be considered how far paleo-anthropological research could be extended to this area, where many more caves of the type that made Sterkfontein famous exist and where hominid fossils have already been found, notably the $1^{\text {st }}$ discovery of a fragment of Boskop Man (Dart, 1954). More adventurous tourists interested in speleology, abseiling, caving, cave diving (a very popular sport in the karst area of Florida, USA) could also be accommodated, with the 6 longest caves certainly offering a range of tourist attractions. Efforts to develop a Luxury Spa at Bovenste Oog on the upper Mooi River have meanwhile been abandoned. While it is commendable that this was one of the first activities allowing a broader public to enjoy the scenic beauty of clear, blue karst springs in a dry environment, concerns were raised about the environmental impacts associated with partial removal of wetlands at the site. In principle, however, it should be encouraged to make large karst springs such as the Bovenste Oog ('Uppermost Eye') and the Gerhard Minnebron (GMB) Eye more accessible to the public and, inter alia, to revitalise the weekend tourism that existed in the past when visitors from Potchefstroom, for example, used the GMB spring as a popular picnic site (Liebenberg, 2007). Accompanied by measures ensuring that no adverse affects such as water pollution can occur, this would offer an opportunity to inform a broader public about the significance of karst springs, not only as water sources but also as unique habitats of wet islands in dry areas, with many species being endemic to karst springs. This, in turn, could contribute to raising public awareness and subsequently promote acceptance and support for conserving such sites. Examples of large karst springs serving as tourist attractions are found worldwide (e.g. 'Blautopf' und 'Rhumequelle' in Germany, many springs in Florida) as well as elsewhere in South Africa, including the Kuruman Eye, the Wondergat and the Molopo Eye, to name but a few. Should springs such as the Oberholzer and Bank Eyes not be reactivated after re-watering, they could still be incorporated on a theme-route on karst illustrating the long-term impacts associated with deep-level gold mining. Such a route could also include the Rand Water Museum at Zuurbekom pumping station, illustrating the pivotal role dolomitic water assumed in the early days of Johannesburg and thus indirectly for the development of South Africa since the world's largest gold deposit was discovered in 1886 on the Witwatersrand.

\section{Mining-related tourism}

With the world's 3 deepest gold mines (at mine closure) being located in the study area, the FWR and its rich history will most certainly attract educational tourism with a special mining interest from overseas as well as from South Africa. Apart from being able to use superlatives such as the deepest mines, largest ice plant, richest reefs, etc., this could also include the fascinating history of the role of water and karst in the development of mining. Tours to open (and meanwhile filled) sinkholes, caves and shafts as well as establishing dedicated (high-tech) information points at which dramatic events such as the 1968 flooding of Driefontein GM and the formation of catastrophic sinkholes are illustrated through the latest 3D-animation computer technology, are among the many possibilities. It may also include virtual underground mine tours from Carletonville to Johannesburg along the interconnected voids of the different mines, an overview on fascinating research and technology associated with deep-level mining in South Africa, including National Geographic video material on groundbreaking shaft sinking and cooling technology developed in South Africa, planned condensation experiments using the kilometre-deep shafts to understand cloud-formation, the detection of primordial organisms in juvenile groundwater at the bottom of shafts, etc.

Such a theme could also be linked to historical events such as the infamous 'Jameson Raid' thwarted at Doornkop ('thorn hill', south of Krugersdorp), where a monument commemorates the failed early attempts by some (not all) 'Rand Lords' (White corporate elite members) to gain control over the newly discovered riches. With these ambitions finally culminating in the AngloBoer War (1899-1902), local sites commemorating the war in the area (such as the Danie Theron Monument near Mponeng Mine, the concentration camp in Potchefstroom, the paleo-sinkhole near Doornfontein GM in which the Reitz commando hid, etc.) could well be linked to the gold-mining history following selfguided routes aided by cellulartelephone technology. Attempts to interest a younger audience may include packages that provide a realistic experience of the challenges of deep-level gold mining, including operating equipment at the rock face, experiencing original hostel food and accommodation and pouring of gold, as well as taking part in dinners at historical sites such as the Recreation Club of Blyvooruitzicht, re-enacting the lavish fashion, food and lifestyles of the days of the Rand Lords.

In addition to gold, the history of uranium-mining in the area could also be included, from its initiation through the Manhattan Project after World War II to the establishment of the uranium pilot plant in South Africa at Blyvooruitzicht GM (1949), the opening of first fully operational uranium plant at West Rand Consolidated GM in Randfontein in 1952, and the establishment of NUFCOR in the area as the world's largest continuous producer of uranium concentrate. With 4 major goldfields being linked by a $2 \mathrm{~h}$ drive along the N12 (Central Rand, West Rand, FWR and Klerksdorp), a more regional approach to promoting mining tourism should be considered. Apart from gold and uranium mining, such an approach could also include mines extracting the other 2 most precious commodities found on earth, i.e., diamonds and platinum, which are also present in the wider region. With mining being intimately linked to geology, such a regional concept could also profit from a visit to the recently-proclaimed Vredefort Dome World Heritage Site (near Parys). Since auriferous conglomerates mined elsewhere in the Witwatersrand also surface at the impact site, a long-standing controversy between mining proponents and conservationists adds further interest to the site.

\section{Wasteland transformation}

The concept of transforming liabilities such as sinkholes, abandoned hostels and shafts into tourist attractions can also be extended to the other problems such as large areas of farmland degraded by ground instability, as well as slimes dams which cover an estimated $50 \mathrm{~km}^{2}$ in the WFS catchment. Some of these opportunities are discussed below. 


\section{Sinkhole areas}

The Deputy Director for sustainable development of GFL recently suggested the possibility of donating the entire land owned by the FWRDWA to local municipalities in order to establish a 'Big 5' game reserve stretching close to $50 \mathrm{~km}$ along the lower part of the WFS (Jacobzs, 2007). Located in a malaria-free area less than 1 hour's drive from Gauteng, this may well prove to be an economically viable and sustainable option complemented by other tourism-related activities mentioned.

\section{Slimes dams (SD)}

Apart from efforts to 'green' decommissioned slimes dams, options should be investigated regarding the extent to which these large wastelands can be used for producing biofuels, which are lately increasingly blamed for causing food prices to rise by occupying land formerly used for food production. If conditions could be created allowing the growth of biofuel plants on slimes dams the use of oilseed rape could be considered. As a major crop for bio-energy, it was recently found to suffer from a sulphur deficiency owing to the successful desulphurisation of the atmosphere in efforts to combat acid rain (Nachtigall, 2008). Since sulphur is abundant in slimes dams this crop may be better suited than others for this relatively hostile environment.

Alternative usage could relate to the generation of renewable energy in form of solar power and wind energy. It should be investigated to what extent the highly reflective, large areas on top of slimes dams could be used in aiding the generation of solar power, given that South Africa is not only currently experiencing a power shortage, but also enjoys one of the highest numbers of annual sunshine hours worldwide. This is particularly true for the large, interior plateau ('Highveld'), where almost all slimes dams are located and where generally sunny winters would allow for using solar power when it is needed most. With respect to utilising the high albedo of slimes dams installations, up-wind solar power stations should be considered where dome-like structures of transparent material, such as glass or plastic foil, channel convectional air flow through a chimney on top, which in turn drives a wind turbine. A prototype of this technology recently successfully commenced operation in Manzanares (Spain).

Apart from providing a sustainable source of decentralised energy (minimising transmission losses) to the often particularly densely-populated mining areas in which slimes dams are located, such power stations and the associated coverage of the tailings would also prevent the infiltration of rainwater, which is a major driving force behind seepage-related water pollution by decommissioned slimes dams. Moreover, wind- and waterborne erosion of slimes dams, which are major threats to their long-term stability and are a source of environmental pollution, would also be minimised. Furthermore, part of the generated energy could be used to cover costs for pumping and treating polluted groundwater commonly found below tailings deposits, thus allowing for cost-optimised remediation of a major environmental impact associated with slimes dams.

In view of the fact that wind speed increases exponentially with height above the earth's surface, the possibilities of using the $20 \mathrm{~m}$ to $50 \mathrm{~m}$ high slimes dams as locations for wind turbines should also be explored. Adding turbines of conventional height would drastically increase wind energy efficiency by tapping into the much higher wind power at the $100 \mathrm{~m}$ above ground levels, without incurring the higher construction costs. Again, as in the case of the earlier-mentioned generation of hydropower underground, location of most slimes dams in densely-populated areas with high energy consumption would allow for the reduction of transmission losses associated with centralised power distribution grids.

It is not clear to what extent current efforts to rework tailings for producing uranium, and re-deposition on a mega-SD near Fochville, will alleviate slimes dam-related pollution. Apart from possible spillages of tailings material during its transport in long pipelines stretching over many tens of kilometres, existing mega-SD structures, such as the ERGO SD in the East Rand, were found to not perform well in terms of associated pollution. Of even greater concern may be the reactivation of dormant underground pollution plumes, triggered by the massive injection of large volumes of high-pressure water used to hydraulically re-mine the slimes dams; this is an aspect which has, to our knowledge, not yet been investigated.

The category of 'liabilities turned into opportunities' may also comprise environmental rehabilitation, which apart from being costly often results in developing local scientific and engineering expertise that may well become a major export product. With the radioactive pollution of the WFS and mine void flooding already attracting international interest, export of rehabilitation-related knowledge may also have development potential.

\section{Uranium: Legacy and future potential}

With uranium having been identified by government in late 2006 as a 'strategic mineral' for securing a nuclear energy supply, the production and enrichment of uranium, as well as possibly nuclear waste, recycling is set to become a $\mathrm{n}$ industry of long-term strategic importance for South Africa (Olivier, 2006; Anonymous, 2007). This strategy currently enjoys generous support from the International Atomic Energy Agency (IAEA), of which South Africa has been an official member state since 1957. Formalised in a $2^{\text {nd }}$ Country Programme Framework (CPF) for the period 2005 to 2010, South Africa signed for IAEA funds for a total of 61 projects focusing on matching nuclear technology with identified priorities for South Africa's sustainable development, including agricultural and livestock production, human health, water resource development, environmental management and integrated pollution control, energy, human capital for nuclear science and technology and capacity building (Moodley, 2006). It should be explored to what extent CPF-related projects may assist in understanding and addressing historical impacts of uranium mining on the environment as well as human health. Only by fully appreciating shortcomings in the past can future mistakes be avoided. This, in turn, will be crucial for establishing public acceptance of nuclear technology as a possible option for post-mining development.

Owing to the existence in the study area of long-standing expertise on uranium-related aspects, including mining, enrichment, nuclear power generation and environmental and health effects, it should also be explored to what extent the area could benefit from a future uranium-based industry. With regard to existing infrastructure, the area is suitable in terms of a number of aspects, including the presence of the Nuclear Fuels Corporation (NUFCOR), the North-West University (NWU), the location of the only functioning heat exchange model of the Pebble Bed Modular Reactor (PBMR), the preferred technology for envisaged nuclear power 
generation in South Africa, and with other researchers at NWU specialising in environmental and geo-ecological aspects of uranium-mining.

Further indications of the area already developing into a hub of the uranium industry include the recent opening of a dedicated uranium mine at Dominion (Klerksdorp area, which owing to the receding uranium price is currently not operational), the re-opening of 2 closed GMs for mining uranium (Ewezulini, Buffelsfontein GM) as well as several planned projects for the extraction of uranium from reworked slimes dams (e.g. Chemwes/Mine Waste Solution, Uranium One, Mintails, GFL, AngloGold Ashanti, Durban Roodepoort Deep, Rand Uranium, Harmony GM).

The extent to which further development of a uraniumbased industry will be acceptable or even desirable to local residents, who have been concerned about radioactive pollution for more than 4 decades, is, however, uncertain. It appears that the current public resistance against uranium is not directed at nuclear technology in general, or associated facilities such as the NUFCOR plant or the PBMR specifically, but rather at the uncontrolled pollution of the environment and the impact on humans caused by a poorly-regulated mining industry in the past.

\section{Mine voids as ultra-deep nuclear waste repositories?}

Given the fact that the safe storage of nuclear waste is a major challenge of nuclear power generation it could be explored to what extent certain parts of the over $4 \mathrm{~km}$ deep mine void could be suited to serve as an ultra-deep repository for nuclear waste. By offering an option to store radioactive waste deeper (and thus safer) underground than any other economically feasible alternative could possibly provide, a significant source of long-term revenue generation in the area could be created. The economic potential of such a disposal facility may be indicated by an offer South Africa received as early as 1984 from West Germany and the USA, together offering a sum of ZAR $1 \mathrm{bn}$. for using a radioactive waste site in the country (Rand Daily Mail, 1984). With nuclear energy generation worldwide currently experiencing significant growth, associated with increasing problems to identify safe disposal sites, it is likely that there will be rising demand in the future for safe, long-term repositories. It needs to be stressed, however, that owing to the inherent danger of radioactive waste this should only be considered a conceivable option if the safety of residents can be guaranteed.

\section{Underground carbon dioxide storage}

With increasing implementation of financial instruments to counteract global warming through curbing the emission of greenhouse gases, the mine void could also be used to commercially store carbon dioxide from coal-based power stations. With proposed prices for emission certificates of $€ 30 / \mathrm{t} \mathrm{CO}_{2}$ (ZAR360/t $\mathrm{CO}_{2}$ ) and the likely continuation of coal-based power generation in a coal-rich country such as South Africa, this could well be a commercially viable option. Possible technologies include the transformation of gaseous $\mathrm{CO}_{2}$ into solid carbonate, storage in salt water, treatment of coal ash with $\mathrm{CO}_{2}$ and others (Schneider, 2005).

\section{Synopsis (Parts 1 and 2)}

Although century-old deep-level gold mining has impacted adversely on the natural environment causing large-scale land degradation and long-term pollution of water, soils and sediment, many mainly water-related opportunities have been presented here to break the dependence of mining towns on mines as sole provider of income and economic survival. Currently many of these opportunities may in fact be no more than dreams, or visions, rather than cut-and-dried development options. However, scale and diversity of identified opportunities suggest that negative mining legacies can be overcome and that alternatives to 'ghost town scenarios' becoming manifest in future exist.

The advantage of soaring commodity prices extending the productive lifespan of many local gold mines by several decades should be used by municipalities to proactively address post-mining development together with government and the mining industry. This includes securing the relevant data, knowledge and expertise for as long as mines are still operational, in order to create a sound base for post-mining decision making. Apart from coping with socio-economic implications of mine closure, such as rise in unemployment, loss of revenue, etc., threats to postmining development in the FWR area may include longterm environmental pollution and largely unknown effects associated with re-watering in the medium- to long-term. Adverse effects currently experienced in the WR suggest that mechanisms, dynamics and effects of re-watering must be clearly understood before the process can be allowed to commence. Potential threats associated with uncontrolled flooding of the mine voids include an initial, severe water shortage in the WFS lasting between 15 and 60 years, during which almost no water would be available for maintaining aquatic ecosystems, farming activities, diluting municipal wastewaters and, last but not least, recharging the Boskop-Turffontein Compartment as sole supply of drinking water to approximately 300000 inhabitants of the Potchefstroom municipal area. In a worst-case scenario this period of filling the mine void and the de-watered dolomitic compartments could be followed by highly polluted, radioactive mine-water decanting, via a number of yet unknown points including existing springs that currently supply potable water to the Mooi River system, accompanied by large-scale reactivation of sinkholes in denselypopulated areas. It is argued that such a scenario must be avoided through a combination of building up adequate rehabilitation funds by the mining industry, governmental control and improved scientific understanding.

On such a base it seems possible to not only avert worstcase scenarios but also to capitalise on the perceived negative mining legacy by turning liabilities into opportunities. The focus of this paper in 3 parts is on water and karst, as largely underutilised and partly misused resources in the area. Possible opportunities for post-mining development include the utilisation of the large karst aquifers for evaporation-free groundwater storage and harvesting, complemented by underground hydropower and hydrothermal energy generation. This can be complemented effectively by what in this paper is termed 'aqua production', relating to the production of water-based products such as fish and reeds. Based on the concept of virtual water, the possible re-establishment of (pumping cost-neutral) irrigation schemes should aim for growing high value products instead of water-intensive low value crops produced more cheaply elsewhere.

With tourism in South Africa growing steadily in economic significance, the establishment of tourist attractions in an area less than an hour away from Gauteng, the largest metropolitan 
area in South Africa, may not only attract overseas travellers but also stimulate domestic weekend tourism. Potential tourism activities in the area may range from organised sightseeing tours to self-drive educational routes real-mine experience packages and ecotourism and adventure holidays, all integrated in a regional tourism concept connecting different areas of interest.

A $3^{\text {rd }}$ major component of post-mining development discussed in this paper is the creative transformation of perceived wastelands into assets offering development opportunities. Options include the transformation of land on unstable cavernous dolomite into a game reserve as well as possible use of vast tailings deposits for biofuel production and renewable energy generation. The extent to which the development of a uranium-related industry is economically feasible and, more importantly, politically desirable is, however, largely uncertain, given the negative publicity uranium currently receives in the area.

Lastly, it is hoped that the suggested generation of knowledge required to proactively avert the manifestation of environmental and socio-economic worst-case scenarios will create a pool of world class scientific expertise. In view of the fact that mining, karst and water are topics relevant to many regions worldwide, such expertise may well become one of the top export products to emerge from the FWR mining experience.

\section{References}

ANONYMOUS (2007) Government (the original spelling used the abbrevation) identifies uranium as 'strategic mineral' to secure nuclear energy supply. Mining Weekly online, 12 February 2007. URL: www.miningweekly.com (Accessed 12 February 2007).

BARTHEL R (2007) Assessment of the radiological impact of the mine water discharges to members of the public living around Wonderfonteinspruit catchment area. BSA Project No. 0607-03, BS Associates, Consulting Engineers and Scientists. Unpublished report to the National Nuclear Regulator (NNR), Contract No. RRD/RP01/2006, Bedfordview. 225 pp.

COETZEE H, WADE P, NTSUME G and JORDAAN W (2002) Radioactivity study on sediments in a dam in the Wonderfonteinspruit catchment. Council for Geoscience Report to DWAF, Pretoria (unpublished).

COETZEE H, WINDE F and WADE P (2006) An Assessment of Sources, Pathways, Mechanisms and Risks of Current and Potential Future Pollution of Water and Sediments in Gold Mining Areas of the Wonderfonteinspruit Catchment (Gauteng/North West Province, South Africa). WRC Report No. 1214/1/06. Water Research Commission, Pretoria, South Africa.

CONNELLY RJ and ROSEWARNE PN (1984) Development of the Groundwater Resources of the Transvaal Dolomites. Proposal to Rand Water Board. Report CI. 4043/1 (January 1984). GH 3422, Vol. 1, Pretoria (unpublished).

DART RA (1954) Africa's Place in the Human Story. SABC Publication. SABC, Auckland Park, Johannesburg.

DWAF (DEPARTMENT OF WATER AFFAIRS AND FORESTRY, SOUTH AFRICA) (2008) URL: Www.dwaf.gov.za/orange/Vaal vaaldam.htm (Accessed 29 May 2008).

DWAF (DEPARTMENT OF WATER AFFAIRS AND FORESTRY, SOUTH AFRICA) (2005) A Guideline for the Assessment, Planning and Management of Groundwater Resources within Dolomitic Areas in South Africa. Volume 1: Conceptual Introduction ( $2^{\text {nd }} \mathrm{draft}$, unpublished).

ENSLIN JF and KRIEL JP (1971) The assessment and possible use of the dolomitic groundwater resources of the Far West Rand, Transvaal, South Africa: Water for Phase 2. DWAF Technical Report No. GH 1849. Department of Water Affairs and Forestry, Pretoria (unpublished).
GIEGERICH P (2008) Umweltfreundlich und kostensparend: Heizen mit Stollenwasser. Informationsdienst Wissenschaft. URL: http:/ idw-online.de/pages/de/news272336 (Accessed 6 August 2008). 2 pp.

IWQS (INSTITUTE FOR WATER QUALITY STUDIES) (1999)

Report on the radioactivity monitoring programme in the Mooi River (Wonderfonteinspruit) catchment. Report No. N/C200/00/ RPQ/2399. Department of Water Affairs and Forestry, Pretoria (unpublished). $26 \mathrm{pp}$.

JACOBS P (2008) Personal communication, 12 April 2008. Environmental officer of Gold Fields Ltd., FWR operations.

JACOBZS W (2007) Personal communication, 5 May 2007. Gold Fields Ltd. Director for Sustainable Development South African operations.

LIEBENBERG W (2007) Personal communication, 11 November 2007. Former Head of DWAF Regional Office, Potchefstroom.

MOODLEY N (2006) SA, IAEA sign 5-yearr nuclear pact. Mining Weekly online, 5 December 2006. URL: www.miningweekly.com (Accessed 7 December 2006).

NACHTIGALL G (2008) Climate change will enforce sulphur deficiency in crops. Informationsdienst Wissenschaft. URL: http://idw online.de/pages/de/news252718 (Accessed 28 March 2008). 2 pp.

OLIVIER M (2006) SA states its case for uranium-enrichment at IAEA. Mining Weekly online, 19 September 2006. URL: Www. miningweekly.com (Accessed 19 September 2006).

RAND DAILY MAIL (1984) Response of Prime Minister PW Botha to enquiry of Brian Goodall, 30 July 1984, p. 36; cited in 'Radioactive Waste' Worldwide Report and South Africa: Nuclear chronology 1944 - 2006. URL: www.nti.org .../ SAfrica/Nuclear/2149.html (Accessed June 2008).

RAND WATER (1904 et seq.) Annual Reports from 1904 to 2008. Rand Water (unpublished).

SCHNEIDER S (2005) Bundesministerium für Forschung und Bildung fördert integratives Forschungsprogramm zur unterirdischen Speicherung des Treibhausgases $\mathrm{CO}_{2}$. Informationsdienst Wissenschaf. URL: http://idw-online.de (Accessed 21 September 2005).

SWART CJU, STOCH EJ, VAN JAARSVELD CF and BRINK ABA (2003a) The Lower Wonderfontein Spruit: an exposé. Environ. Geol. 43 635-653.

SWART CJU, JAMES AR, KLEYWEGT RJ and STOCH EJ (2003b) The future of the dolomitic springs after mine closure on the Far West Rand, Gauteng, RSA. Environ. Geol. 44 751-770.

VEGTER JR (1983) Moontlikhede van Stedelike Watervoorsiening uit Dolomietgesteentes in die Bedieningsgebied van die Rand Waterraad. Geohydrological Report No. GH3298. Department of Water Affairs and Forestry, Pretoria (unpublished).

WADE PW, WOODBOURNE S, MORRIS WM, VOS P and JARVIS NV (2002) Tier 1 Risk Assessment of Radionuclides in Selected Sediments of the Mooi River. WRC Report No. 1095/1/02. Water Research Commission, Pretoria, South Africa.

WINDE F, STOCH EJ and ERASMUS E (2006) Identification and Quantification of Water Ingress into Mine Voids of the West Rand and Far West Rand Goldfields (Witwatersrand basin) with a View to Long-Term Sustainable Reduction thereof. Final report, Project No. 5512, Council for Geoscience, Pretoria (unpublished). 261 pp.

WINDE F (2006a) Impacts of gold-mining activities on water availability and quality in the Wonderfonteinspruit catchment. In: Coetzee H, Winde F, Wade P (eds.) An Assessment of Sources, Pathways, Mechanisms and Risks of Current and Potential Future Pollution of Water and Sediments in Gold Mining Areas of the Wonderfonteinspruit Catchment (Gauteng/ North West Province, South Africa). WRC Report No. 1214/1/06. Water Research Commission, Pretoria, South Africa. 13-34.

WINDE F (2006b) Challenges for sustainable water use in dolomitic mining regions of South Africa - a case study of uranium pollution. Part I: sources and pathways. Phys. Geogr. 27 (2) 335-346.

WINDE F (2006c) Challenges for sustainable water use in dolomitic mining regions of South Africa - a case study of uranium pollution. Part II: Spatial patterns, mechanisms and dynamics. Phys. Geogr. 27 (2) 379-395. 
WINDE F (2009): Uranium pollution of water resources in minedout and active goldfields of South Africa - A case study in the Wonderfonteinspruit catchment on extent and sources of U-pollution and associated health risks. Proc. 2009 International Mine Water Conference, 19-23 October 2009, Pretoria, South Africa.

WINDE F and STOCH EJ (2010a) Threats and opportunities for postclosure development in dolomitic gold mining areas of the West
Rand and Far West Rand (South Africa) - a hydraulic view. Part 1: Mining legacy and future threats. Water $S A 36$ (1) 69-74.

WITTMANN GTW and FÖRSTNER U (1977): Heavy metal enrichment in mine drainage: The Klerksdorp, West Wits and Evander. Goldfields. S. Afr. J. Sci. 73 53-57.

ZUBER-KNOST E (2003) Wasser aus der Höhle. Informationsdienst Wissenschaft, URL: http://idw-online.de (Accessed 12 May 2003). $2 \mathrm{pp}$. 